\title{
Symmetric and asymmetric alternations in direct object encoding
}

Iemmolo, Giorgio

DOI: https://doi.org/10.1524/stuf.2013.0019

Posted at the Zurich Open Repository and Archive, University of Zurich

ZORA URL: https://doi.org/10.5167/uzh-82236

Journal Article

Published Version

Originally published at:

Iemmolo, Giorgio (2013). Symmetric and asymmetric alternations in direct object encoding. STUF Language Typology and Universals, 66(4):378-403.

DOI: https://doi.org/10.1524/stuf.2013.0019 
Volume $66 \cdot 2013 \cdot$ Issue 4

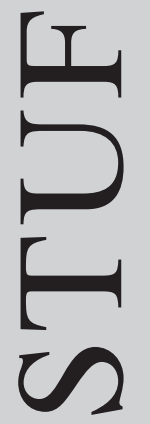

Language Typology
and Universals

Sprachtypologie und Universalienforschung

Editor-in-chief: Th. Stolz, Bremen Executive editor: C. Stroh, Bremen

Editorial Board: W. Bisang, Mainz $\cdot$ W. Croft, Albuquerque $\cdot$ W. U. Dressler, Wien R. Fabri, Malta · J. A. Flores Farfán, México · L. Gunkel, Mannheim · S. Haberzettl, Saarbrücken B. Hurch, Graz · M. Koptjevskaja-Tamm, Stockholm · S. Michaelis, Leipzig M. Mithun, Santa Barbara · C. Moyse-Faurie, Villejuif · D. Nübling, Mainz · I. Putzu, Cagliari W. Raible, Freiburg · J. Sakel, Bristol $\cdot$ Ch. Schroeder, Potsdam E. Schultze-Berndt, Manchester · Ch. Stolz, Bremen · E. Verhoeven, Bremen

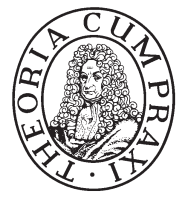


"STUF" is a forum for scholarly articles in the realm of linguistic typology and universals research. The journal covers original empirical and/or theoretical studies of the structural diversity and/or of the invariants of human language(s). Equally welcome are contributors to submit papers with a leaning towards areal typology and/or diachronic typology.

Please send manuscripts to STUF - Language Typology and Universals, Executive editor C. Stroh, Universität Bremen, Fachbereich 10, Postfach 330440, D-28334 Bremen, e-mail: cornelia.stroh@uni-bremen.de.

Orders should be addressed to:

Rhenus Medien Logistik GmbH \& Co. KG, Justus-von Liebig-Straße 1, D-86899 Landsberg, Phone: +49-819197000-214, Fax: +49-8191-97000-594, E-mail: degruyter@de.rhenus.com.

\section{STUF - Language Typology and Universals}

Editor-in-chief: Prof. Dr. Thomas Stolz, Universität Bremen, Fachbereich 10, Postfach 330440, D-28334 Bremen, Phone: +49-421-2187565, Fax:+49-421-2184283, E-mail: stolz@uni-bremen.de.

Publisher: Akademie Verlag GmbH, Genthiner Str. 13, D-10785 Berlin, Phone: +49-30-260 05-167.

Managing director: Dr. Sven Fund.

Advertising office: Christina Gericke, Akademie Verlag GmbH, Phone: +49-30-260 05-167,

E-mail: gericke@akademie-verlag.de.

Typesetting: WERKSATZ Schmidt \& Schulz GmbH, Gräfenhainichen.

Printed by: Concept Medienhaus GmbH, Berlin.

Subscription information: STUF is published as one volume of four issues per year. Subscription rates for Volume 66 (2013): Institutional (print and online) $€ 308.00$ (postage extra). Single issue $€ 79.00$ (postage extra).

Private (print and online) $€ \mathbf{7 9 . 8 0}$ (postage extra).

Subscription runs for further 12 months, if it is not cancelled at least 8 weeks before the end of the subscription period.

Copyright: It is a general condition that submitted manuscripts have not been published and will not - without written consent by the publishers - be submitted or published elsewhere. By submitting a manuscript, the authors agree that the copyright for their article is transferred to the publisher if and when the article is accepted for publication. The copyright covers the exclusive rights to reproduce and distribute the article, including reprints, photographic reproduction, microform or any other reproductions of similar nature, and translations. Photographic reproduction, microform, or any other reproduction of text, figures or tables from this journal is not allowed without permission obtained from the publisher.

Printed on durable paper.

2013 Akademie Verlag GmbH, Berlin. Ein Unternehmen von De Gruyter. 


\title{
Symmetric and asymmetric alternations in direct object encoding*
}

\begin{abstract}
This paper examines two different strategies found in direct object encoding on the basis of a sample of 159 languages. In particular, this paper deals with the differences between symmetric (i.e. the alternation between two or more overt markers) and asymmetric (i.e. the alternation between a zero and one of more overt markers) alternations. The investigation is aimed at determining whether there are any evident cross-linguistic regularities with respect to the factors involved in these two kinds of alternation. It will be argued that the difference in the formal realization of direct object encoding is related to the distinct functions that these two structures perform cross-linguistically. While asymmetric alternations are regulated by referential properties of the direct object referent, symmetric alternations are governed by parameters related to verbal semantics, such as affectedness and boundedness, polarity, and quantification.
\end{abstract}

Keywords: symmetric and asymmetric alternation, differentiated object marking, verbal aspect/ actionality, partitive case, identifiability

\section{Introduction}

Alternations in direct object (DO) encoding have been the subject of many studies in the past two decades. In particular, many studies have dealt with asymmetric (after DE Hoop \& MALchúov 2008) alternations in DO encoding, such as the one found in Persian, in which only definite DOs receive overt coding, while the others stay uncoded, as in (1):

(1) Persian (Indo-European, Indo-Iranian)

(1a) Hasan ketab-râ did

Hasan book-ACC see:PST.3sG

'Hasan saw the book'

* This research was carried out in the frame of and financially supported by the Grant No. BI 799/5-1 (2009-2012, PI BAlThaSAR BicKel) from the Deutsche Forschungsgemeinschaft as part of the EuroBABEL programme of the European Science Foundation (Collaborative Research Project ID 577, led by Katharina Haude). A previous version was presented at the $45^{\text {th }}$ Meeting of the Societas Linguistica Europaea, Stockholm, August 29 - September 1 2012. I would like to thank the audience for insightful comments and helpful questions, as well as Balthasar Bickel, Sonia Cristofaro, Bill Croft, Francesca di Garbo, Eitan Grossmann, Silvia Luraghi, Manana Topadze, Fernando ZÚÑIGA, and two anonymous reviewers for their comments on earlier drafts of this paper. The usual disclaimers apply. 

Hasan ketab did
Hasan book see:PST.3sg
'Hasan saw a book'

[Comrie 1989,132]

This phenomenon is nowadays very well known under the label of Differential Object Marking (henceforth, DOM) (AIssen 2003; Bossong 1985, 1998; Comrie 1989, Croft 1988, Iemmolo 2011, Dalrymple \& Nikolaeva 2011, among others). Cross-linguistically, as will be further discussed below, DOM systems are triggered by semantic and/or informationstructural properties of the DO referent, such as animacy, definiteness, specificity and topicality. Such properties are often represented through hierarchies (CROFT 2003):

- Animacy: human > animate > inanimate

- Definiteness: definite $>$ specific indefinite $>$ non-specific indefinite

- Topicality: topical > non-topical

DO referents ranking higher on the hierarchies are likely to be overtly coded, as opposed to DO referents ranking lower on the hierarchies, which are less likely to be overtly coded.

Recently, some scholars working mainly in the Optimality-Theory framework (DE SWART 2006, 2007; DE Hoop \& Malchukov 2008; Malchukov 2005) have investigated not only cases in which the alternation in DO encoding is asymmetric, as in the Persian examples we have seen above, but also cases in which there is a symmetric alternation between two (or more) overt markers, as exemplified by (2) from Finnish:

(2) Finnish (Uralic, Finnic)

(2a) hän jo-i maido- $n$.

s/he drink-PST.3sg milk-ACC

'S/he drank (all) the milk'

(2b) hän jo-i maito-a.

s/he drink-PST.3sg milk-PART

'S/he drank (some of the) milk'

[KITTILÄ 2002:114]

The DO in (2a) is in the accusative case, while the one in $(2 b)$ is in the partitive. The use of a different case marker is reflected in the translation: the accusative case implies that all the available milk is gone, while the partitive case suggests that only some of the available milk was consumed.

An interesting treatment of the motivations behind symmetric and asymmetric systems of DO encoding has been proposed by DE Hoop \& MALchukov (2008). In their view, casemarking systems obey two different and violable constraints, seen as competing motivations, namely DISTINGUISHABILITY and IDENTIFY. DISTINGUISHABILITY requires case marking to disambiguate between the two core arguments of a transitive clause (DE HoOP \& MALCHUKOV 2008, 584). IDENTIFY serves to encode specific semantic/pragmatic information about the nominal argument in question via case marking. Interestingly, DE HoOP \& MALCHUKov (2008) relate the two above-mentioned different functions of DOM to the two different structural types of DO encoding we have introduced in section 1 (DE Hoop \& Malcurov 2008: 573 ff.), i.e. the asymmetrical and the symmetrical one. While asymmetrical DO encoding can be due to both DISTINGUISHABILITY or IDENTIFY, symmetrical DO nroding, as in the case of Finnish, must be necessarily due to IDENTIFY. 
De Hoop \& Malchukov (2008)'s model of case marking elegantly accounts for the variation found in DO encoding, since it establishes a connection between two different morphosyntactic patterns of DO encoding. Nonetheless, DE Hoop \& MALCHuKov (2008)'s account mainly deals with the OT-rules behind this formal alternation, without investigating the parameters that govern the two patterns. Furthermore, some of the peculiarities that set asymmetric alternations apart from symmetric alternations are not taken into account in their analysis. For instance, in discussing the alternation between accusative and partitive in Finnish, DE Hoop \& MALCHUKov (2008) do not mention that the partitive case can alternate with the nominative in subject function. As we will see below, the partitive case cross-linguistically does not share the distribution of any other case-marking device (MorAVCSIK 1978), for it does not indicate the dependency relation between a noun and its head, being found on subjects, DOs, and obliques (SANDS \& CAMPBELL 2001:256-269).

In this paper, I will investigate the role of semantic and information structural factors behind the alternations in DO encoding. As I will argue in the following, there are significant differences between symmetric and asymmetric systems.

Based on a convenience sample of 159 languages, as well as from some languages outside the sample, I will show that these two structural types of DO encoding fulfill different functions cross-linguistically. While DOM has a strong link with either referential properties of the DO referent or information structure, as it is often used i) to indicate a high degree of topicality of the DO, and ii) to signal topic shifts and topic promotions in discourse (IEMMOLO 2011), symmetric alternations such as the one found in Finnish are employed to signal differences in verbal aspect/actionality, polarity, and quantification.

As a matter of fact, I will argue that in asymmetric systems parameters like affectedness, verbal aspect/actionality or quantification, do not play a primary role, whereas these are the main parameters underlying symmetric alternations. I will also show that the asymmetric alternation seems to be cross-linguistically more common than the symmetric one.

In short, I will argue that:

- When there is a symmetric alternation in DO encoding, such alternation will be governed by parameters related to verbal aspect/actionality, polarity, or quantification;

- Conversely, asymmetric alternations will be mostly governed by referential (i.e semantic or information structural) properties of the DO, such as animacy, topicality, and definiteness (i.e. identifiability/referentiality).

The paper is organized as follows. Section 2 presents the data on the cross-linguistic distribution of symmetric and asymmetric alternations respectively. Section 3 discusses the purported connection between affectedness and DOM in Mandarin Chinese and Spanish. Section 4 summarizes the main findings of the paper.

\section{The cross-linguistic data}

This study is based on a sample of 159 languages. As I have already mentioned above, symmetric systems in which the alternation applies rather consistently across verbal classes (it is not restricted to just a handful of verb classes) seem to be fairly rare cross-linguistically. Whereas just 26 (i.e. $16 \%$ ) of the 159 languages show symmetric alternations in DO encoding, asymmetric alternations (i.e. DOM) are manifested by 133 (84\%) of the languages. Interestingly, genetic and areal factors appear to be involved in the distribution of 
symmetric alternations. In fact, symmetric alternation are mostly found in the CircumBaltic area (comprising both Finnic and Indo-European languages), in some ancient IndoEuropean languages, as well as in the Kartvelian family. Outside Eurasia, symmetric alternations are found in some Polynesian languages. However, the available data make it impossible to advance any hypothesis as to the typological frequency of the phenomenon.

Keeping these distributional differences in mind, let us now examine the pat- terns of symmetric versus asymmetric encoding of DOs.

\subsection{Symmetric systems}

The alternation between accusative and partitive on DOs is one of the most well-studied features of Finnic languages. I will now examine the distribution of these two cases in Finnish, which has been taken as an example of symmetric DOM. According to HuUmo (2009: 88), DOs can be encoded in the partitive case if they are:

i) in negated sentences, ii) in aspectually unbounded sentences (more precisely: atelic, progressive, cessative, and irresultative (semelfactive) sentences, and iii) in sentences where the object NP refers to an open, indefinite quantity.

The following examples illustrate the difference in verbal aspect brought about by use of the accusative (3) as opposed to the partitive case (3b). (3c) exemplifies the use of the partitive in negated sentences, where the partitive is in fact the only available option:

(3) Finnish (Uralic, Finnic)

(3a) Rakens-i-n

build-PST-1sG

'I built a house'

(3b) Rakens-i-n talo-n talo- $a$

build-PST-1SG house-ACC house-PART

'I was building a/the house - I did some house building'

[Huumo 2003: 115]

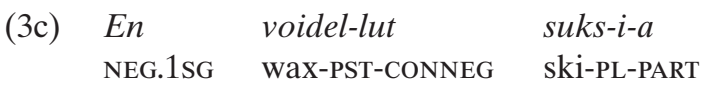

'I was not waxing/did not wax (the) skis'

[Huumo 2009: 94]

It has been proposed that the partitive case correlates with a low degree of transitivity of the sentence, which often results in a low affectedness of the DO (see NÆSs 2004, 2007). However, as observed by (LuRAGHI ms), the use of the partitive does not necessarily entail a lower degree of affectedness, as shown by the different interpretations given for example (4).

(4) Finnish (Uralic, Finnic)
sotilaa- $t$
tappo-i-vat
vihollis-i-a
soldier-PL.NOM
kill-PST-3PL
enemy-PL-PART

(4a) 'The soldier were killing enemies' (imperfectivity+indefiniteness of DO)

(4b) 'The soldier killed some enemies' (indefiniteness of DO only)

(4c) The soldier were killing the enemies' (imperfectivity only)

[LURAGHI ms] 
The same sentence is open to three different interpretations. The sentence can be construed either as having an imperfective reading along with an indefinite DO (a), or as having an indefinite DO (b), or an imperfective aspect only (c). Interestingly, the affectedness of the DO is in principle independent from the use of the partitive case. As is clear from the translations given in (b) and (c), the DO is affected in both cases. What matters in these cases is the definiteness of the DO, since the DO can be conceived of either as indefinite or definite (LuRAGHI \& KitTILÄ in press). There seems to be no difference as to the degree of affectedness of the DO, since in both cases the DO undergoes a change of state (BEAVERS 2011; CROFT 2012). ${ }^{1}$ Rather, the use of the partitive brings about a difference in definiteness and quantification, which is something hardly ever found in DOM systems.

I have already mentioned above that the distribution of the partitive case, and its counterparts in other languages, does not match the functions commonly assigned to case marking, namely that of indicating a dependency relation between a noun and its head (BLAKE 1994: 1). In fact, the partitive case occurs also on subjects and on a variety of adpositional complements, alternating with the nominative or the genitive (HuUmo 2003: 462). When used on subjects, the partitive often triggers an existential reading (see HuUmo 2003; SANDS \& CAMPBELl 2001 for discussion and examples).

Summing up, we have seen that the alternation between accusative and partitive in Finnish conveys differences related to quantification (i.e. the definiteness/indefiniteness distinction), and verbal aspect (with the partitive signaling imperfectivity as opposed to the accusative, which signal perfectivity). ${ }^{2}$ Similar constraints, with due consideration for the differences between individual cases, are found in most Finnic languages (such as Estonian, Karelian, Votic, etc.).

Unlike Finnic languages, Hungarian does not possess a dedicated partitive marker that can be used as an alternative to the accusative. In order to express a partitive meaning, Hungarian resorts to the ablative, as shown by the examples (5):

(5a) Ette a sütemény-t
eat.PST.3sG-OBJ the pastry-ACC
'S/he ate the pastry'
(5b) Evett a süteménytból
eat.PST.3SG the pastry-ABL
'S/he ate some of the pastry'

[MoRAVCSIK 1978]

The difference brought about by the use of the ablative concerns the quantity of the DO referent, rather than its affectedness. In (5b), only part of the pastry has been actually consumed, while in (5a), the event pertains the whole DO referent. As far as the degree of affectedness is concerned, however, the change of state is identical, since in both cases the pastry has been consumed: the difference lies only in the quantity affected by the action.

1 That the partitive does not always signal a lower degree of affectedness is also confirmed by the fact that partially affected DOs in Finnish tend to appear in the elative case, rather than in the partitive (KoptJevSKAJA-TAMm \& Wälchli 2001: 652).

Further alternations, which will not be dealt with here, are related to verbal classes. For instance, the second argument of verbs of liking, thinking, understanding and knowing is in the elative case (KARLSSON 2003:111), while the second argument of the verb "to love" must be in the partitive case (KARLSSON 2003: 82). 
The symmetric alternation in DO encoding is also found in many Indo-European languages. For Baltic and some Slavic languages, an areal pattern can be identified (see KoptJEVSKAJA-TAмm \& WÄLCHLi 2001) For instance, in Lithuanian, DOs can be encoded in the genitive if they are in negated sentences or refer to an indefinite quantity (HoLvoET 2011: 17-18). Otherwise, the DO will be in the accusative. A similar pattern is found in Polish (Przepiórkowski 2000), Slovene (Herrity 2000), and Old Church Slavonic (LunT 2001), where DOs are obligatorily put in the genitive if the verb is negated. The genitive is instead optional when the DO refers to an open quantity and is thus used to convey a definiteness/indefiniteness distinction. Once again, the genitive can be used on subjects of existential sentences: unlike Finnic languages, the sentence must be negated for the genitive case to be used.

The alternation between accusative and genitive in Russian differs from Finnic and Baltic languages in some respects. First of all, the use of genitive with DOs under negation is not obligatory, unlike in Polish, Slovene, and Old Church Slavonic, as shown by the examples (6), where there is alternation between genitive and accusative even if the verb is negated (see KrASOVITSKY et al.2011 for a discussion on the factors influencing this alternation).

(6) Russian (Indo-European, Slavic)

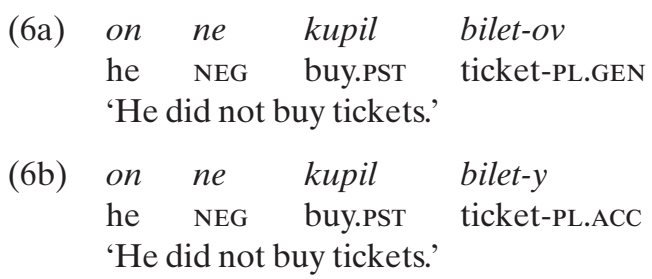

[KRASOVITSKY et al.2011:575]

The choice between accusative and genitive is still connected to the domains of quantification and aspect, as shown by the examples in (7). In fact, the alternation between accusative and genitive to encode differences in quantification is available only with perfective verbs. Imperfective verbs do not generally allow such an alternation, most probably due to the fact that DOs of imperfective events are usually interpreted as referring to an open quantity (KoptJevsKajA-TAмм \& WäLchli 2001: 655). Nonetheless, in some Russian dialects, imperfective verbs do allow genitive DOs as well (cf. KoptJEvSKAJA-TAMm \& WÄLCHLI 2001:655):

$$
\text { Russian (Indo-European, Slavic) }
$$

$\begin{array}{lll}\text { on } \quad \text { vypil } & \text { molok-a } \\ \text { 3sG.M.NOM } & \text { drink.PFV.3sG } & \text { milk.GEN } \\ \text { 'He drank some milk.' } & \end{array}$

$\begin{array}{lll}\text { on } & \text { vypil } & \text { molok-o } \\ \text { 3sG.M.NOM drink.PFV.3sG } & \text { milk.ACC } \\ \text { 'He drank (all) the milk.' } & \end{array}$

[WADE 2011:107]

Symmetric alternations are also found in many ancient Indo-European languages well. For instance, Gothic, Old High German, and Old Saxon display an alternation between genitive and accusative which is very much comparable to the one found in Russian (ABRAHAM 1997; PHILIPPI 1997 and references therein), in so far as the alternation between the wo case forms is available only with perfective verbs, whereas DOs governed by imper- 
fective verbs must be obligatorily put in the accusative. Moreover, the genitive is also used to refer to open quantities as well as with DOs in negated sentences (see WrigHT 1910: 184 for examples). ${ }^{3}$

In Ancient Greek, the genitive could alternate with the accusative to signal that only a sub-part of the referent is affected, as shown by the examples in (8); (cf. NAPOLI 2010: 26):

Classical Greek (Indo-European, Greek)

$\begin{array}{lccc}\text { pleúsantes } & \text { es Leukáda } & \text { tēn } & \text { Korinthíōn } \\ \text { sail:PTCP.PRS.NOM.PL } & \text { to Leucas:ACC } & \text { ART.ACC.SG.F } & \text { Corinthian:GEN.PL } \\ \text { apoikian tés } & \text { gês } & \text { étemon } \\ \text { colony:ACC } & \text { ART.GEN.SG land:GEN.SG } & \text { ravage:AOR.3PL } \\ \text { 'Sailing to Leucas, the colony of Corinthians, they ravaged the country.' }\end{array}$

[Thuc. 1.30.2; LURAGHI ms]

(8b) hoi

$\begin{array}{llll} & \text { Elềoi } & \text { Lereatōn } & \text { tên } \\ \text { ART.NOM.PL.M } & \text { Elean:NOM.PL } & \text { Lepreate:GEN.PL } & \text { ART.ACC.F } \\ \text { gên } & \text { étemon } & & \\ \text { land:ACC.SG } & \text { ravage:AOR.3PL } & & \end{array}$

'The Eleans ravaged the land of the Lepreates.'

[Thuc. 5.31.3; LuRAGHI ms]

A similar state of affairs is found in Early Vedic and Avestan, where the genitive/accusative alternation is attested with both definite and indefinite DOs, and is instead related to the boundedness of the event, with the genitive case used form unbounded events and the accusative for bounded ones (DAHL 2009). The alternation between accusative and genitive is also very marginally present in Early Latin (BAUER 2007:133), but is no longer attested in the Classical period.

We have seen so far that the symmetric alternation in DO encoding between accusative and partitive/genitive in Balto-Finnic languages, as well as in some ancient and modern Indo-European languages is conditioned by polarity (Balto-Finnic, Slavic, Gothic), aspect/ actionality (Balto-Finnic, Greek, Early Vedic, Aves-tan), quantification (Balto-Finnic, Slavic, Gothic, Greek, Early Vedic, Avestan).

Outside the Indo-European family, consistent symmetric systems are found in the Altaic languages Evenki, Negidal (Tungusic), and Dolgan (Turkic). DOs in Evenki can be encoded via three different case markers, namely the "definite accusative" (-Va- $m A)$, the "indefinite accusative" $(-y=A)$, and the nominative case plus the reflexive-possessive suffixes.

3 Abraham (1997), Philippi (1997) have explained the alternation in old Germanic languages as a means to encode a definiteness/indefiniteness distinction, due to the fact that at the time Germanic languages had not developed yet a system of determiners. However, it is debatable whether this is the main function of the alternation in Gothic and Old High German, as well as in Russian (ABRAHAM 1997: 45-46). It is hard to see how the alternation between accusative and genitive in Gothic can be considered primarily as a definiteness-marking strategy. As a matter of fact, we do find examples in which the genitive is used primarily to denote open quantities, as well as with negated sentences containing definite DOs that are within the scope of negation. Thus, the choice of the genitive case over the accusative does not correlate only with an indefinite-definite distinction. Rather, it is primarily associated with polarity, boundedness, and quantification, as in the other languages we have discussed thus far. The definite-indefinite distinction brought about by the use of the accusative vs. the genitive seems to be a by-product of their main function, which is that of indicating that only a (sub)-part of the DO referent is affected (see LURAGHI \& KITTILÄ in press for a historical account of this process) 
The latter strategy is restricted to definite possessed DOs when the possessor is coreferential with the subject, in which case the use of the definite accusative is forbidden (NEDJALKOV 1997:147;192-194). The conditions governing the choice of the definite accusative over the indefinite one are rather complex. The definite accusative is used whenever the DO is definite: however, an indefinite interpretation is available also for DOs encoded by the definite accusative, as shown by example (9):

(9) Evenki (Altaic, Tungusic)

(9a)
oron-mo
java-kal
reindeer-DEF.ACC take-PRS.IMP.2SG

'Catch that reindeer.'

(9b) tar asi kniga-va tay-jara-n

that woman book-DEF.ACC read-PRS-3sG

'That woman is reading a/the book.'

[Nedjalkov 1997:193]

The indefinite accusative is used to encode indefinite and partitive DOs, as in (10a) and (10b) respectively: ${ }^{4}$

(10) Evenki (Altaic, Tungusic)
(10a) oron-o java-kal
reindeer-INDEF.ACC take-PRS.IMP.2SG
'Catch yourself a/any reindeer.'
(10b) $\min -d u$ ulle-ye kolobo-yo by:-kel
1SG-DAT meat-INDEF.ACC bread-INDEF.ACC give-IMP.PRS.2SG
'Give me (some) meat and (some) bread'

(10c) beye mo:ka-r-e genne:-vki

man stick-PL-INDEF.ACC bring-HAB

'The man usually brings firewood.'

[Nedjalkov 1997:193-194]

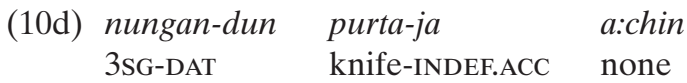

'He hasn't a knife.'

[NEDJALKov 1997: 97]

Based on the data I have discussed so far, the parameters at work in the Evenki system appear to be comparable to those found in an asymmetric system. Nevertheless, there are further restrictions on the distribution of the two case markers that support the affinity with the symmetric cases I have discussed above. The definite accusative is the only possible option with past tenses, while the indefinite accusative case is the only available option with i) the future indicative, ii) the imperative (10a), and iii) verbs that bear the habitual aspect suffix (10c). Furthermore, the indefinite accusative tends to appear when the sentence is negated (Nedjalkov 1997: 194 and Bulatova \& Grenoble 1999: 9).

The Indefinite accusative is used also to mark the beneficiary, (see Nedjalkov 1997: 147). Moreover, the incefinite accusative is also used in privative constructions with the negative noun $a$ :čin 'none', thus corroborating the link of this marker with negation. 
Thus, the definite accusative aligns with bounded, perfective events, being the only option with past tenses expressing completed events. The indefinite accusative, instead, is mainly confined to contexts implying no boundedness of the event and a lower degree of involvement of the DO. Albeit not identical, this distribution is reminiscent of the alternation between accusative and partitive/genitive we have discussed above. A similar distribution is attested for Negidal (Tungusic) and Dolgan (Turkic) (cf. PAKENDorf 2007: 172-173 for discussion).

A few Kartvelian languages (Georgian, Mingrelian, Svan) display a symmetrical DO alternation dependent on TAM parameters. For instance, in Georgian, DOs are differently encoded depending on the TAM series of the verb. ${ }^{5}$ Thus, the DO in (11a) is in the dative with imperfective tenses (TAM series I), while the DO in $(11 \mathrm{~b}, \mathrm{c})$ occurs in the nominative with the aorist and the perfect series respectively (i.e. TAM series II and III):

(11) Georgian (Kartvelian, Georgian)

\begin{tabular}{|c|c|c|c|}
\hline (11a) & $\begin{array}{l}\text { glex-I } \\
\text { peasant-NOM } \\
\text { 'The peasant is }\end{array}$ & $\begin{array}{l}\text { tesavs } \\
\text { 3sG.SUBJ.Sow.3sG.I } \\
\text { sowing corn.' }\end{array}$ & $\begin{array}{l}\text { simind-s } \\
\text { corn-DAT }\end{array}$ \\
\hline$(11 b)$ & $\begin{array}{l}\text { glex-ma } \\
\text { peasant-ERG } \\
\text { 'The peasant s }\end{array}$ & $\begin{array}{l}\text { datesa } \\
\text { 3sG.SUBJ.sow.3sG.II } \\
\text { wed corn.' }\end{array}$ & $\begin{array}{l}\text { simind-i } \\
\text { corn-NOM }\end{array}$ \\
\hline 1c) & $\begin{array}{l}\text { glex-s } \\
\text { peasant-DAT }\end{array}$ & $\begin{array}{l}\text { dautesavs } \\
\text { 3sG.SUBJ-Sow.3sG.III }\end{array}$ & $\begin{array}{l}\text { simind- } i \\
\text { corn-NOM }\end{array}$ \\
\hline
\end{tabular}

[HARRIS 1981:1]

As expected, the symmetric alternation found in DO encoding in Georgian does not rely on any referential properties of the DO referent, but is rather dependent on tense-aspect features.

Some Polynesian languages exhibit a symmetric alternation, known as "middle object construction" (Chung 1978), which is slightly different from the cases we have seen so far, inasmuch as it seems to be more closely connected to verbal classes than in the cases we have analyzed so far. Middle object constructions involve a change in DO encoding (as well as in subject encoding, but I will not consider it here) whereby the DO takes oblique encoding instead of the standard accusative or absolutive case (depending on whether the languages is accusative or ergative). This distinction is exemplified by (12), where the totally affected DO is encoded by the accusative preposition (12a), as opposed to the less affected one (12b), which is introduced by an oblique preposition: ${ }^{6}$

Maori (Austronesian, Oceanic)

$\begin{array}{lllll}\text { (12a) } & K a \quad k a p o \quad a u & i & \text { te } & \text { puu } \\ \text { T/A snatch 1sG ACC the gun } \\ \text { 'I snatched the gun.' }\end{array}$

5 Georgian has three series of TAM forms. Series I or the "Present(-future)" series (which comprises the present, the imperfect, the future, the conditional, and two subjunctives), Series II or the "Aorist" series (which consists of the aorist, the optative, and the imperative, and Series III or the "Perfect" series (present and past perfect tenses, commonly used as evidentials) (HARRIS 1981,1985).

This pattern in some respect mirrors the conative alternation found in English, as shown by the translation of the examples. See section 3 for discussion. 
(12b) Ka kapo au kite puи T/A snatch 1sG to the gun

'I snatched at the gun.'

[BAUER 1993:268]

The distribution of the two overt markers is generally lexically-based. For instance, the majority of verbs that do not entail a high degree of affectedness of their object, like perception or emotion verbs such as "look at, listen to, like, want, respect", select the oblique preposition instead of the accusative one (CHUng 1978: 47), as in Maori, Niuean (SEITER 1980), Tongan, and Tuvaluan (Besnier 2000). However, this rule does not apply consistently across the board, as demonstrated by the fact that there are quite a number of such verbs that either select the accusative over the oblique or display alternation between the two forms of the kind exemplified by (12). Interestingly, in Niuean, as well as in Tuvaluan, the alternation between the two markers can be also employed to convey a partitive meaning $(13 a, b)$ or an incomplete action $(13 c, d)$ :

(13) Niuean (Austronesian, Oceanic)

(13a) Ko kai a mautolu he talo

PRS eat ABS 1PL.EXCL at taro

'We are eating (some) taro.'

(13b) Ko kai e mautolu e talo

PRS eat ERG 1PL.EXCL ABS taro

'We're eating up the taro.'

(13c) ne kitia e fānau he magō

PST see ABS children at shark

'The children caught a glimpse of a shark.'

(13d) ne kitia he fānau e magō

PST see ERG children ABS shark

'The children saw a shark.'

[SEITER 1980:34]

As illustrated by the examples above, the symmetric alternation found in Polynesian languages is essentially governed by verbal parameters, such as affectedness and aspect, and can be thus considered akin to the other symmetric alternations we have seen above. Unlike the systems we have examined above, however, this alternation has been almost completely conventionalized in these languages, as shown by the fact that, with many verbs, the only available option is the oblique.

Thus, summing up what we have seen so far, it appears to be clear that symmetric alternations are regulated by verbal semantics, polarity, and quantification. I will show in the next section that these parameters do not play any role in asymmetric alternations, which are instead associated with referential properties of the DO referent.

\subsection{Asymmetric systems}

Asymmetric alternations, commonly referred to as DOM, are by far more common in the languages of the world (133 languages out of 157 in my sample). Each case has been coded with respect to the main parameter(s) (i.e. the parameter that takes priority over the 
others) influencing the presence of overt coding for DOs. The distribution of DOM relative to the main parameter is shown in Table 1 (IEmmolo 2011):

\begin{tabular}{l|l|l}
\hline Parameter & No & $\%$ \\
\hline Animacy & 45 & 33 \\
\hline Topicality & 86 & 64 \\
\hline Dislocation & 60 & 45 \\
\hline Definiteness & 3 & 1 \\
\hline
\end{tabular}

Table 1: Distribution of DOM systems relative to the main parameter

As shown by Table 1, the most recurrent factors for the presence of DOM cross-linguistically are the humanness/animacy and topicality of the DO. Only two languages show definiteness alone as the main parameter: these languages are Modern Hebrew and Malagasy, where DOM is obligatory with syntactically definite DOs, i.e. DOs that are modified by determiners, demonstratives, or possessives, regardless of information structure distinctions. In 45 (i.e. $33 \%$ ) of these languages, animacy takes priority over the other parameters, in that DOM is always present when the DO is animate and/or human. Maltese (AfroAsiatic, Semitic) nicely illustrates the restriction of DOM to animate DOs, as shown by the examples in (14):

(14) Maltese (Afro-Asiatic, Semitic)

$\begin{array}{llll}\text { (14a) Tereza rat } & \text { lit-tifel/ } & \text { it-tifel } \\ \text { Therese see.PST.3sG.F } & \text { DOM.DEF-boy/ } & \text { DET-boy } \\ \text { 'Therese saw the boy.' } & & \end{array}$
(14b) Marija qabdet il-ballun
Mary catch.PST.3sG.F DET-ball
'Mary caught the ball.'

[BORG \& MiFSUd 2002: 35]

DOM is primarily governed by the topicality of the DO in 86 (i.e. $64 \%$ ) of the languages in the sample, in that topical DOs tend to be overtly coded as opposed to non-topical ones. This constraint is very often associated with the obligatory presence of DOM with dislocated or topicalized DOs or with positions reserved to topical referents (60 languages, i.e. $45 \%$ ), as opposed to non-dislocated or non-topicalized ones, as shown by the examples in (15) from Chepang (Tibeto-Burman). When the basic SOV word order is followed, no DOM occurs (15a), as opposed to (15b), where the DO is in initial position and thus receives DOM:

Chepang (Tibeto-Burman)

$\begin{array}{lll}\text { (15a) } & \begin{array}{l}\text { PuP-nis-Pi } \\ \text { older_brother-DU-ERG }\end{array} & \text { sat-Paka-c-u } \\ & \text { younger_brother } & \text { kill-PST-DU-A }\end{array}$

'The two older brothers killed the younger brother.'

$$
\begin{array}{lcc}
\text { həw-kay } & \text { pu?-nis-?i } & \text { sat-Pa-thəy } \\
\text { younger_brother-ACC } & \text { older_brother-DU-A } & \text { kill-PST-OBJ } \\
\text { 'The two older brothers killed the younger brother.' }
\end{array}
$$

[CAughley 1982: 68] 
In other cases, the topicality requirement is not directly linked to the position of the DO in the clause. For instance, in Altai (Altaic, Turkic), only topical, presupposed DOs receive DOM, while no DOM is allowed with focal DOs. Examples (16a) and (16b) nicely illustrate the topicality requirement for the presence of DOM. (16a) is the reply to the question "And who is the best student in their class?", where Aržana is left uncoded since it constitutes the focal portion of the sentence. By contrast, (16b) is a reply to the question "How is Aržana?", where Aržana is the presupposed, topical element. As expected, the direct object in (16b) must be overtly coded:

Altai (Altaic, Turkic)

$\begin{array}{lllll}\text { (16a) Aržana d'akši } & & \text { üren-ip } & \text { tur-gan } & \text { dežet } \\ \text { Aržana } & \text { well } 1 & \text { earn-CONV } & \text { AUX-PFV.3SG } & \text { HSY }\end{array}$

'They say that Aržana studies well.'

$\begin{array}{lllll}\text { Aržana-n̈̈ d'akši } & \text { üren-ip } & \text { tur-gan } & \text { dežet } \\ \text { Aržana-Dom } & \text { well } & \text { learn-CONV } & \text { AUX-PFV.3SG } & \text { HSY } \\ \text { 'They say that Aržana studies well.' } & & \end{array}$

[SKRIBNIK 2001:352]

The restriction of DOM to topical DOs is very widespread in the languages of the world, as can be appreciated from Table 1. My analysis of DOM systems in the languages in the sample, as well as in additional languages from outside the sample, suggests that the link between DOM and topicality is motivated by the function that DOM systems perform in discourse. I have already mentioned above that DOM systems are overwhelmingly associated with two major construction types, namely topicalizations and dislocations, as well as with positions reserved to topical referents, like the preverbal position in many Sinitic languages (see LA Polla 1995). In all the languages where a close link between DOM and these structures/positions exist, DOM is employed to encode topic discontinuities, such as topic shifts and topic promotions. That is, DOM is generally associated with the re-introduction of a referent after a gap of absence in the discourse (see IEmmolo 2011) for discussion and examples).

DOM systems synchronically based on animacy provide further support for the primacy of topicality in the emergence of such systems. Where diachronic evidence is available (as in the case of many Indo-European languages), or it is possible to reconstruct previous stages in the development of the construction (as in some Uralic or Sino-Tibetan languages), it can readily be seen that DOM systems that appear to be based on animacy and definiteness synchronically are in fact a result of the grammaticalization of earlier topicality-based systems (Iemmolo 2011; Dalrymple \& Nikolaeva 2011). Basically, DOM in these languages was extended from topical DOs to DOs that show features usually associated with topics, like animacy or definiteness (see Givón 1976 and papers therein, Comrie 1989; CROFt 2001 on the connection between topicality and animacy/definiteness). Over time, DOM was thus extended and conventionalized to animate DOs, irrespective of their actual information status, as observed, e.g. in Romance (IEmmolo 2010; Iemmolo 2011) and Uralic (Marcantonio 1985; Dalrymple \& Nikolaeva 2011).

In addition, the primacy of topicality can be observed synchronically when "optional" contexts are taken into account. As Table 1 shows, in many languages, DOM is primarily dependent upon semantic features of the DO, such as animacy. In these languages, DOM is obligatery with some NPs (usually those higher on the animacy/definiteness hierarchies), and optional with less animate/definite NPs. In my analysis, the appearance of DOM and 
DOI is in fact never optional. Rather, in these cases, topicality is the decisive factor in determining the usage of overt coding (see also DALRYMPLE \& NiKolaeva 2011 for similar observations). That is, DOM appears only if the NP is topical. As a consequence of increasingly high frequency, DOM further grammaticalize with that NP class and are no longer optional, being also reanalyzed as neutral as to their information status. This process is easily detectable in several unrelated languages (Indo-European, Dravidian, Nilo-Saharan, Tucanoan, Uralic, among others).

Nonetheless, for some languages, such as Mandarin Chinese (Sino-Tibetan, Sinitic; Li \& Thompson 1981) and Spanish (Indo-European, Romance, von Heusinger \& KaIser 2011) among others, it has been argued that properties related to verbal semantics, like e.g. affectedness, are in fact relevant in the appearance of DOM. In the next section, I will discuss in depth the cases of Mandarin Chinese and Spanish. I will show that affectedness plays no role either in the development of the construction or in its synchronic distribution.

\section{Affectedness and asymmetric alternations: the cases of Mandarin Chinese and Spanish}

Mandarin Chinese has a construction, commonly referred to as "the $b a$ construction" (Li AND ThOMPSON 1981: 463) in which the DO is placed after $b a$ but before the verb (Chinese basic word order is SVO). ${ }^{7}$ The use of this construction is regulated by a number of constraints. In order for a $b a$-sentence to be grammatical, the following three conditions must be fulfilled (YIP \& Rimmington 2004: 200 ff., LiU 2007, among others):

- $b a$ cannot be used with post-verbal DOs;

- $b a$-marked DOs should have definite or specific referents;

- the predicate must be complex, i.e. the main verb has to be followed by another constituent indicating boundedness (see below).

Animate and human DOs show a strong tendency to be overtly coded, although a human DO can show up uncoded, as illustrated by examples $(17 \mathrm{a}, \mathrm{b})$, in which the pronoun "him" is overtly coded in the former case and uncoded in the latter:

(17) Mandarin Chinese (Sino-Tibetan, Sinitic)

(17a) wo ba ta sha-le

1sG BA 3 SG.M kill-PFV

'I killed him.'

(17b) wo sha-le ta-(le)

1SG kill-PFV 3SG-PFV

'I killed him.'

[Li 2006: 377]

7 The status of $b a$ is quite controversial in the literature. Whilst most linguists agree that $b a$ is synchronically a preposition (CHAO 1968; YANG \& VAN BERGEN 2007; YANG 2008, among others), many studies have proposed an analysis of $b a$ as a verb (BENDER 2000), as a dummy case that fills the head of a causative phrase when there is not verb raising (Sybesma 1992), and as a coverb (Li \& Thompson 1981). In this paper, $b a$ will be considered as a preposition, due to the fact that $b a$ does not behave as a verb, as demonstrated by Sun (1996) and discussed by Li (2006). 
A large and growing body of literature has investigated the $b a$ construction, and many analyses have been proposed to account for its distribution (LI \& THOMPSON 1981; SuN 1996; Li 1990, among others) ${ }^{8}$

According to one influential line of research, the use of $b a$ in Chinese is regulated by the degree of affectedness of the DO. Sentences containing DOs marked by $b a$ have often been argued to express disposal (a calque of a Chinese term roughly meaning affectedness), i.e. "how a person is handled, manipulated, or dealt with; how something is disposed of; or how an affair is conducted" (WANG 1947, quoted in JING-SchmidT 2005: 67). In this view, DOs have to be highly affected by the event in order to be overtly coded (Li 2006, Li \& Thompson 1981: 465). Disposal analyses have been later incorporated into the Transitivity Hypothesis proposed by Hopper \& THOMPson (1980). Within this framework, $b a$ is analyzed as a marker of high transitivity (Li \& Thompson 1981; Sun 1996), since it occurs with highly definite objects and is subject to a number of aspectual constraints (LIU 1997), such as event boundedness. $B a$-sentences in Chinese require the verb be followed by a constituent signaling "event boundedness" (i.e. telicity), such as the resultative marker $d e$, the perfective marker -le or a quantified phrase (LiU 2007).

The fact that the event has to be bounded and the DO definite or at least specific has led many linguists to claim that what $b a$ signals is the affectedness of the DO, as advocated by, e.g. (Chao 1968; Li \& Thompson 1981; Sun 1996), among others. Liu (1997), however, does not consider this constraint as conclusive evidence for a close connection between affectedness and the presence of $b a$. It should be further noted that the event boundedness hypothesis is challenged by the fact that $b a$ marking is compatible with the durative atelic marker $z$ he (JING-SCHMIDT 2005: 167). In addition, as PEYRAUBE (1985: 195) observes, a verb alone may be found in final position if it is bisyllabic.

The idea that affectedness - defined as the degree of specificity of a predicate as to the change undergone by a participant along a scale of possible changes (see BEAVERS 2011: 358, CRоFт 2012: ch. 6) - determines the appearance of $b a$ does not actually hold in the light of the data.

If it were so, one would expect that $b a$ be used only with predicates entailing a high degree of affectedness of their DOs, being instead optional or disallowed with verbs entailing a low degree of affectedness or no affectedness at all. This condition, however, does not hold either synchronically or diachronically. As a matter of fact, $b a$ is never obligatory with high affectedness verbs, nor is it disallowed or disfavored with low affectedness verbs. Rather, the distribution of $b a$ in Chinese is mainly regulated by information structural parameters.

Let us quickly examine the range of verbs that can occur with the $b a$-construction. Since affectedness is seen as the primary parameter governing the presence of $b a$, we would expect that the marker should not be allowed when the predicate entails a low degree of affectedness or no affectedness at all. On the contrary, the marker should be obligatory when the predicate implies high affectedness.

Since it is not our purpose here to propose an account that encompasses all the facets of the $b a$-construction, but rather to test the alleged connection between the presence of $b a$ and affectedness, we wil not discuss in detail other analyses that have been put forth to account for the distribution of the $b a$-construction. See Li (2006), who provides a thorough summary of the literature. 
The examples in (17) above are a clear case in point. The DO "him" is governed by the verb kill in both examples. Although kill entails a complete, definite change in both cases, $b a$ can be omitted, and the SVO counterpart is used instead, without bringing about any difference in the degree of affectedness of the DO. Similarly, the DO "orange" in (18) appears either with $b a$ or uncoded. In both cases, the orange has undergone a change of state, having been peeled off. Nonetheless, the marker can be left out:

Mandarin Chinese (Sino-Tibetan, Sinitic)

\begin{tabular}{|c|c|c|}
\hline$(18 \mathrm{a}) \quad v$ & $\begin{array}{ll}w o & b a \\
1 \mathrm{SG} & \mathrm{BA}\end{array}$ & $\begin{array}{l}\text { juzi } \\
\text { orange }\end{array}$ \\
\hline
\end{tabular}

(18b) wo bo-le juzi

1SG peel-PFV orange

'I peeled the orange.'

[Li 2006: 418]

Although the DO is affected in both cases at the same degree, a counterpart without $b a$ is possible. In addition, the $b a$-construction occurs with verbs implying low affectedness or no affectedness at all. In fact, many examples are found in which the $b a$-marked DO is governed by stative or psychological predicates, as in (19):

(19) Mandarin Chinese (Sino-Tibetan, Sinitic)

$\begin{array}{lllll}\text { (19a) wo } & \text { ba } & \text { ta } & \text { demingzi } & \text { wangji-le } \\ \text { 1SG } & \text { BA } 3 \mathrm{SG} \text { DET name } & \text { forget-PFV } \\ \text { 'I forgot her name.' } & & \end{array}$

[IEMMOLO \& ARCODIA forthcoming]

$\begin{array}{llllllllll}\text { (19b) ta } & b a & n i & \text { xiang } & \text { de fan } & \text { dou bu not ken chi } \\ \text { 3SG } & \text { BA } & \text { 2SG } & \text { miss } & \text { RES food all not will eat } & \end{array}$

'S/he misses you so much that s/he won't even eat her/his meals.'

[Li \& THOMPSON 1981, 469]

In order to account for the presence of $b a$ in these examples, it has been suggested that the affectedness of the DO need not be physical, but rather psychological or imaginary (such as emotional or subjective "changes", see Li \& Thompson 1981: 469-470). For instance, Li \& Thompson (1981: 470) argue that the use of $b a$ in (19b) is due to the addition of the post-verbal modifier, which conveys a sense or an implication of affectedness along with the verb. This very loose notion of affectedness, which includes emotional and somehow subjective changes, would explain the presence of the marker with stative psychological predicates. A similar explanation, nonetheless, does not fit example (19a), in which there is no post-verbal modifier to signal this "imaginary" affectedness and the DO is not affected at all. Plenty of examples can be found in the literature showing that $b a$ appears with DOs that are not affected by the event expressed by the verb at all. Consider the examples in (20):

(20) Mandarin Chinese (Sino-Tibetan, Sinitic)

$\begin{array}{lllllll}\text { 20a) } & \text { wo } & \text { ba } & \text { nei } & \text { jian } & \text { shiqing liaojie-de } & \text { qing-qing-chu-chu } \\ 1 \mathrm{SG} & \mathrm{BA} & \text { that } & \mathrm{CL} & \text { matter } & \text { investigate-RES } & \text { very_clear }\end{array}$

'I found out all about that matter.'

[JING-SchMidT 2005: 79] 


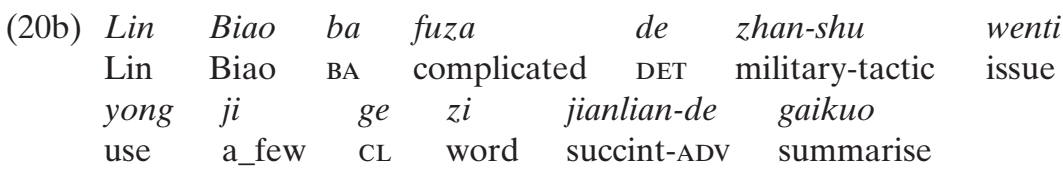

'Lin Biao summarized complicated tactical issues using just a few words.'

[IEMMOLO \& ARCODIA forthcoming]

The predicates in (20) cannot be said to cause any change in their DOs. Nonetheless, $b a$-marking appears. A view that takes affectedness as the main trigger for $b a$ marking fails to account for the many instances in which the DO is not affected at all by the event expressed by the predicate. If affectedness is conceived of as a visible and persistent change of state (BEAVERS 2011) no implication of change can be drawn from the examples above. Likewise, no transmission of force, which is one the crucial parameter for defining affectedness (CROFT 2012:216), is present in all the examples I have discussed.

What then triggers the use of the $b a$-construction? The distribution of DOM in Mandarin Chinese becomes less peculiar when cross-linguistic data from similar systems and information-structure parameters are taken into account. DOM in Mandarin Chinese seems to be, once again, connected with topicality.

Let us briefly examine the properties that corroborate the reliance of Mandarin Chinese DOM upon topicality. First of all, $b a$-coded DOs possess many properties usually associated with topics. They are overwhelmingly associated with given information and highly identifiable referents, as shown by the corpus study in Iemmolo \& Arcodia (forthcoming). Second, $b a$ cannot be used with non-specific referents, which cannot be construed as topical. Third, as pointed out by LA Polla (1993: 310), the preverbal position in Mandarin Chinese is reserved to topical NPs, while focal NPs are generally found in the post-verbal position (see IеммоLo 2011: ch. 7 for further discussion and references on this constraint in languages where DOM derives from serial verb constructions).

Another case in which affectedness has been claimed to be relevant for the development and the appearance of DOM is Spanish. Recently, von Heusinger \& KAISER (2011) have investigated the role of affectedness in the development of DOM in Spanish. They examined the occurrence of DOM in three different centuries $\left(15^{\text {th }}, 17^{\text {th }}\right.$, and $19^{\text {th }}$ century, respectively) with twelve verbs chosen within five of the seven verb classes in the hierarchy identified by TSUNODA (1985), reproduced in (21):

(21) ACTION (kill, break) > PERCEPTION (see, look) > PURSUIT (search, wait for) $>$ KNOWLEDGE $($ know) $>$ FEELING (love) $>$ RELATION (have) > ABILITY (be capable of).

Von Heusinger \& Kaiser (2011) claim that, though affectedness is relevant for the development of DOM in Spanish, it is only a secondary parameter. Their results show that the distribution of DOM with the verb classes identified by TsunODA (1985) is reversed to some extent, as is shown by the comparison between TsunODA's original hierarchy given above and the ranking of verbs with respect to DOM in Spanish:

(22) DOM with definite NPs (von Heusinger \& KAISER 2011): PERception, FeEling, ACTION > PURSUIT, KNOWLEDGE

(23) DOM with indefinite NPs (von Heusinger \& KaISER 2011):

PERCEPTION $>$ FEELING, ACTION $>$ KNOWLEDGE $>$ PURSUIT

VON Heusinger \& KAISER explain the discrepancies between TsunODA's hierarchy and he findings for Spanish, in which perception and feeling verbs rank higher than action 
verbs, by appealing to the notion of agentivity, especially with regard to perception and feeling verbs. In their view, TsunODA's verb hierarchy disregards the fact the some verbs attribute to their DO a feature that is prototypical for subjects, namely the agentivity of human and animate participants (vON HEUSINGER \& KAISER 2011:21). For instance, the DO of the verb temer 'to fear' is agentive, because the DO, which is the stimulus, may bring about a change in the subject, which is the experiencer. Therefore, in cases like this, DOM is not conditioned by affectedness, but is rather driven by the competition between the two arguments when both of them are human and, arguably, agentive.

The notion of agentivity, however, does not seem to work if relation verbs, such as tener, are taken into consideration. The DO of tener can hardly be considered as somehow agentive, nor can it be deemed affected by the event represented by the predicate, which is clearly stative, as in examples (24):

Spanish (Indo-European, Romance)

\begin{tabular}{|c|c|c|c|c|}
\hline $\begin{array}{l}\text { Obama } \\
\text { Obama }\end{array}$ & $\begin{array}{l}\text { ya } \\
\text { already }\end{array}$ & $\begin{array}{l}\text { tiene } \\
\text { have:3sG.PRS }\end{array}$ & $\begin{array}{l}a \\
\mathrm{ACC}\end{array}$ & $\begin{array}{l}\text { su } \\
\text { his }\end{array}$ \\
\hline \multicolumn{5}{|c|}{ 'Obama already has his vice-president.' } \\
\hline Yo & no & tengo & $a$ & nadie \\
\hline 1SG.SUBJ & NEG & have:1SG.PRS & $\mathrm{ACC}$ & nobody \\
\hline
\end{tabular}

Furthermore, tener allowed DOM as far as back the $13^{\text {th }}$ century, as demonstrated by the examples in $(25 \mathrm{a}, \mathrm{b})$, in which DOM is found with a proper name:

(25) Spanish (Indo-European, Romance)

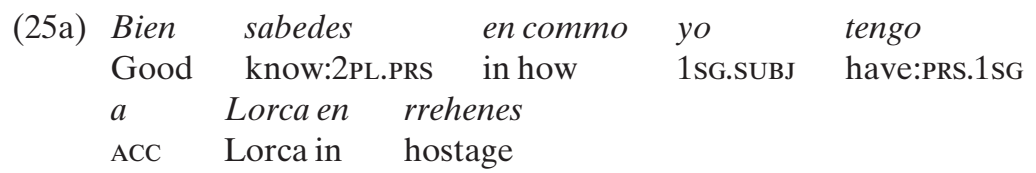

'You know well how I hold Lorca hostage.'

[Anonymous, Cartas de Don Juan Manuel y vasallos suyos enviados al Rey de Granada,1327]

$\begin{array}{llllll}\text { (25b) } & \text { Yo } & \text { tengo } & a & \text { Gandalín } & \text { por uno } \\ \text { 1sG.SUBJ } & \text { have:1sG.PRS ACC } & \text { Gandalín } & \text { for one } \\ \text { delos } & \text { mejores } & \text { escuderos } & \text { del } & \text { mundo } \\ \text { of the } & \text { best } & \text { henchman.PL } & \text { of_the } & \text { world }\end{array}$

'I consider Gandalín as one of the best henchmen in the world.'

[Rodríguez de Montalvo, Amadís de Gaula,1482].

The fact that DOM occurred so early with tener suggests that the role of affectedness, as well as the purported role of agentivity, in determining DOM is at best of little importance. If affectedness were a relevant parameter, we would not expect DOM to appear with stative predicates tener in such an early stage of the history of the construction.

Von Heusinger \& KaIser's data thus corroborate that, in Spanish as well, affectedness cannot be regarded as a crucial parameter in the analysis of DOM, since DOM is significantly more frequent with verbs entailing low affectedness, such as perception and feeling verbs. In addition, it should be noted that two of the verbs chosen as representative of 
TsunODA's first class (i.e. action verbs) were matar 'kill' and herir 'wound', which require their DO to be animate or human. Remarkably, these verbs rank lower than perception or feeling verbs, such as ver 'see' or temer 'fear'.

In fact, other accounts relate the diachrony and the synchronic distribution of Spanish DOM to topicality, as shown by Laca (1995), Pensado (1995), Leonetti (2004) among others. In particular, PENSAdo (1995) has convincingly argued that the development of DOM in Spanish started with the left dislocation of personal pronouns. The influence of topicality is still readily observable in Contemporary Spanish, where DOM becomes obligatory with left-dislocated DOs for which DOM is optional when in post-verbal position, as in (26a) vs. (26b):

(26) Spanish (Indo-European, Romance)

(26a) Habian $\quad \begin{array}{lll}\text { incluido } & \text { (a) dos catedraticos } \\ \text { have.IPFV.3PL include.PTCP.PST ACC two professors } & \text { A } \\ \text { en la lista } & & \\ \text { in the list } & \end{array}$
'They included two professors in the list'

$*(A)$ dos catedraticos, los
ACC two professors 3PL.OBJ have.IPFV.3PL
incluido $\quad$ en la lista
include.PTCP.PST in the list
'Two professors they included in the list.'

[LEONETTI 2004: 15]

The plausibility of this diachronic development is further supported by data from the incipient DOM systems found in other Romance languages, notably Northern Italian, some French varieties, Swiss patois, and Gallo-Italian dialects (IEmmolo 2010).

In conclusion, a closer examination of the distribution and the development of DOM in Mandarin Chinese and Spanish does not provide any conclusive evidence for a fundamental influence of affectedness on this phenomenon. Rather, as expected for an asymmetric alternation, the distribution of DOM correlates with referential properties of the DO, such as topicality, animacy, or identifiability.

Before proceeding to the conclusions to be drawn from the facts discussed in this paper, a caveat is in order. I do not claim that it is not possible to find asymmetric systems governed by parameters like affectedness or aspect. As a matter of fact, such cases do exist. An example is the conative construction found in English, where some verb classes show a transitivity alternation which basically changes a DO into an oblique prepositional phrase (see Levin 1993; Goldberg 1995, among others). This is illustrated by the examples in (27), where the DO "bear" in (27a) becomes an oblique introduced by the preposition at in (27b):

English (Indo-European, Germanic)

(27a) I shot the bear

\section{(27b) I shot at the bear}

Broadly speaking, in the conative construction there is no entailment that the action expressed by the predicate has been actually carried out. This also entails that the second varicipant introduced by the preposition at is not conceived of as necessarily affected by L. I1 
the action, which itself might have been not completed. Similar systems are found in some Australian languages, such as Kalkatungu and Warlpiri (McCloskey \& Hale 1983), where the DO is encoded in the dative instead of the (zero-marked) absolutive when there is no entailment that the action represented by the predicated has affected the DO.

This would seemingly weaken the generalization proposed in this paper regarding the link between the morphological alternations in DO encoding and the triggering factors of such alternations. However, there are some important differences that set the conative alternation apart from the asymmetric systems discussed in section 2 . The conative alternation in the languages discussed above is generally limited to some verb classes, viz. verbs of cutting, hitting, or verbs of consumptions (such as "to eat"), while it is prohibited with, e.g., verbs of touching or breaking (see Levin 1993; Levin \& Hovav 2005; BEAvERs 2010 for discussion). Asymmetric systems of the DOM-type do not display any restriction to any particular verb class depending on its semantics, but are invariably governed by referential properties of the DO, like animacy or topicality. In addition, in the conative alternation the semantic argument of the predicate is morphosyntactically realized as an oblique. In asymmetric systems, there is no such alternation in argument status.

\section{Final remarks}

The investigation of the formal realization of DO encoding has shown that the two forms of morphological encoding are overwhelmingly regulated by different parameters. We have indeed seen that symmetric alternations are regulated by different parameters across languages from those that govern asymmetric ones.

While the former serve to signal differences in polarity, quantification, and verbal semantics, the latter are systematically triggered by referential properties of the DO referent, such as animacy and topicality, and very often serve to signal topic discontinuities in discourse.

One may argue that referential properties, like definiteness, do play a role in symmetric alternations, just like in asymmetric ones. We have seen in section 2.1 that symmetric alternations can be employed to signal (in)definiteness. However, there seems to be a fundamental difference between symmetric and asymmetric systems. In asymmetric systems like DOM, the definiteness distinction is related to the identifiability of the DO referent in discourse, i.e. DOM will be preferentially used when the DO referent can be identified by both the speaker and the hearer or by the speaker only (in this latter case specificity distinctions come into play; see von Heusinger to appear; IEmmolo 2011).

By contrast, the differences in definiteness brought about by symmetric alternations are first and foremost related to quantification rather than to identifiability. That is, the main function of symmetric alternations is to indicate a difference in the quantity of the DO referent that is involved in the action expressed by the predicate. The different encoding does not cause any difference in the identifiability status of the DO referent. It is plausible to refer to an indefinite quantity of a definite, identifiable entity, as shown for instance by the examples from Hungarian and Classical Greek I have discussed above, where the ablative and genitive respectively co-occur with the definite article.

I have also shown that, contrary to what has been sometimes claimed in the literature, e.g., on Spanish and Mandarin Chinese, the role of affectedness in asymmetric systems is negligible, thus lending further support to the idea defended in this paper that the two 
kinds of formal alternations in direct object encoding obey two different functional parameters.

In closing, I would like to mention that I have deliberately avoided the question of why symmetric systems appear to be much rarer cross-linguistically than asymmetric systems. As documented in section 2.1, only 26 out of 159 languages in the sample show a rather consistent symmetric alternation in direct object encoding. This could lead one to think that asymmetric alternations are favored over symmetric alternations. In addition, I have also noticed that symmetric systems seem to be restricted to some linguistic areas (e.g. the Circum-Baltic one) or to some language families (e.g. Indo-European or Finno-Ugric). Therefore, it could well be possible that areal and genetic factors play an important role in the distribution of symmetric systems. The actual impact of such factors, however, has to be tested on a balanced sample in order to make statistical predictions as to the typological frequency of the phenomenon.

This study was primarily motivated by the claims that have been made in the literature about the similarity of symmetric and asymmetric systems with regard to their triggering parameters and their functional motivations. The absence of a cross-linguistic study on the nature of the formal alternations I have analyzed in this paper has made it difficult to evaluate such claims. It is hoped that the current study provides a better understanding of the alternations found in DO encoding as well as a starting point for future research.

\section{A. Appendix: Languages in the sample with asymmetric alternations $(\mathbf{N}=133)$}

\begin{tabular}{l|l|l|l}
\hline Family & Stock & Language & Factors \\
\hline Afro-Asiatic (18) & Cushitic & Dullay & TOP/DISL \\
\hline & & Kemantney & TOP/DISL \\
\hline & & Ts'amakko & TOP/DISL \\
\hline & Egyptian-Coptic & Sahidic Coptic & TOP \\
\hline & Omotic & Haro & TOP/DEF \\
\hline & Semitic & Sheko & TOP/DISL \\
\hline & & Amharic & TOP/DISL \\
\hline & & Aramaic (Biblical and Neo) & AN \\
\hline & & Arabic (Lebanese) & AN \\
\hline & & Argobba & TOP \\
\hline & & Hebrew (Biblical) & TOP/DISL \\
\hline Altaic (11) & & Hebrew (Modern) & DEF \\
\hline & & Maltese & AN \\
\hline & & Silti & TOP/DISL \\
\hline & & Tigrinya & TOP/DISL \\
\hline & Mongolic & Zway & TOP/DISL \\
\hline & & Bao'an & TOP/DISL \\
\hline & & Buriat & TOP/DISL \\
\hline & & Mangghuer & TOP/DISL \\
\hline & Tungusic & Mongolian (Khalkha) & TOP/DISL \\
\hline & & Manchu & TOP/DISL/DEF \\
\hline & Turkic & Udihe & TOP/DISL \\
\hline & & Altai & TOP/DISL \\
\hline & & Kirghiz & TOP/DISL \\
\hline & & Turkish & TOP/DISL/DEF \\
\hline & & Tuvan & TOP/DISL \\
\hline & & Uzbek & TOP \\
\hline & & & TOP \\
\hline & & &
\end{tabular}




\begin{tabular}{|c|c|c|c|}
\hline Family & Stock & Language & Factors \\
\hline Arauan (1) & & Paumarí & TOP/DISL \\
\hline Arawakan (1) & & Tariana & TOP/DISL \\
\hline \multirow[t]{7}{*}{ Australian (7) } & Pama-Nyungan & Arabana & AN \\
\hline & & Dharumbal & AN \\
\hline & & Gunya & AN \\
\hline & & Nhanda & AN \\
\hline & & Pitjantjatara & AN \\
\hline & & Wargamay & AN \\
\hline & & Waga-Waga & AN \\
\hline Austro-Asiatic (1) & & Semelai & TOP \\
\hline \multirow[t]{7}{*}{ Austronesian (7) } & Meso-Philippine & Malagasy (Barito) & DEF \\
\hline & & Hiliganyon & AN \\
\hline & & Tagalog & TOP/AN \\
\hline & Oceanic & Marquesan & TOP/DISL \\
\hline & & Tobati & TOP/DISL \\
\hline & $\begin{array}{l}\text { Northwest Malayo- } \\
\text { Polynesian }\end{array}$ & Begak-Ida'an & AN \\
\hline & Palauan & Palauan & $\mathrm{AN} / \mathrm{DEF}$ \\
\hline Barbacoan (1) & & Awa-Pit & AN \\
\hline \multirow[t]{2}{*}{ Border (2) } & Border & Imonda & AN \\
\hline & Waris & Waris & AN \\
\hline \multirow[t]{4}{*}{ Creoles (4) } & Portuguese-based & Diu Indo-Portuguese & AN \\
\hline & & Kristang & AN \\
\hline & & South African Creole & AN \\
\hline & Malay-based & Manadonese & AN \\
\hline \multirow{5}{*}{ Dravidian (5) } & Southern Dravidian & Badaga & TOP/DISL \\
\hline & & Betta Kurumba & AN \\
\hline & & Kannada & AN \\
\hline & & Malayalam & AN \\
\hline & & Tamil & AN \\
\hline \multirow[t]{16}{*}{ Indo-European (16) } & Armenian & Classical & TOP/DISL \\
\hline & & Western & AN \\
\hline & & Eastern & TOP \\
\hline & Germanic & Afrikaans & AN \\
\hline & Indo-Aryan & Kashmiri & AN \\
\hline & & Hindi & $\mathrm{AN}$ \\
\hline & & Maithili & AN \\
\hline & & Marathi & AN \\
\hline & & Romaní & TOP \\
\hline & Indo-Iranian & Balochi & TOP/DEF \\
\hline & & Persian & TOP/DISL \\
\hline & & Tajik & TOP/DISL \\
\hline & & Vafsi & TOP \\
\hline & & Wakhi & TOP \\
\hline & Slavic & Nasha & AN \\
\hline & & Pomak & AN \\
\hline Klamath-Modoc (1) & & Klamath & TOP \\
\hline \multirow[t]{2}{*}{ Maku (2) } & & Hup & TOP \\
\hline & & Dâw & TOP/DISL \\
\hline \multirow[t]{2}{*}{ Muskogean (2) } & Western & Choctaw & TOP/DISL \\
\hline & Eastern & Koasati & TOP/DISL \\
\hline Niger-Congo (6) & Dogon & Dogon & TOP/DISL \\
\hline 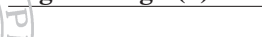 & Kwa & Akan & TOP \\
\hline 5 & & Baule & TOP \\
\hline
\end{tabular}




\begin{tabular}{|c|c|c|c|}
\hline Family & Stock & Language & Factors \\
\hline & & $\mathrm{Ga}$ & TOP \\
\hline & Idomoid & Idoma & TOP \\
\hline & Nupoid & Nupe & TOP \\
\hline \multirow[t]{7}{*}{ Nilo-Saharan (7) } & Fur & Fur & TOP \\
\hline & Maban & Maba & TOP/DISL \\
\hline & Nubian & Dongolese Nubian & TOP \\
\hline & & Uncunwee & TOP \\
\hline & Taman & Tama & TOP \\
\hline & Western Saharan & Kanuri & TOP/DISL \\
\hline & & Tubu & TOP/DISL \\
\hline \multirow[t]{3}{*}{ Oto-Manguean (3) } & Mixtecan & Copala Trique & TOP \\
\hline & Zapotecan & Yaitepec Chatino & TOP \\
\hline & & Zenzopetec Chatino & TOP/DISL \\
\hline \multirow[t]{2}{*}{ Sahaptin (1) } & & Nez Perce & TOP \\
\hline & & Yakima & TOP \\
\hline \multirow[t]{4}{*}{ Sepik (4) } & $\mathrm{Ndu}$ & Manambu & TOP/DISL \\
\hline & Ramu & Awtuw & AN \\
\hline & Tama & Yessan-Mayo & AN \\
\hline & Yellow River & Namia & TOP/DISL \\
\hline \multirow[t]{17}{*}{ Sino-Tibetan (18) } & Chinese & Cantonese & TOP/DISL \\
\hline & & Gan & TOP/DISL \\
\hline & & Hakka & TOP/DISL \\
\hline & & Mandarin Chinese & TOP/DISL \\
\hline & & Southern Min & TOP/DISL \\
\hline & & Xiang & TOP/DISL \\
\hline & Burmese-Lolo & Burmese & TOP/DISL \\
\hline & & Lahu & TOP \\
\hline & Bodic & Chantyal & TOP/DISL \\
\hline & & Chepang & TOP/DISL \\
\hline & & Newari (Dolakha) & TOP \\
\hline & & Kham & TOP \\
\hline & & Magar & AN \\
\hline & & Manange & AN \\
\hline & & Thulung Rai & AN \\
\hline & Kuki-Chin & Meithei & AN \\
\hline & Tani & Galo & TOP \\
\hline \multirow{2}{*}{ Trans New Guinea (2) } & Madang & Anamuxra & AN \\
\hline & Oksapmin & Oksapmin & AN \\
\hline \multirow[t]{7}{*}{ Tucanoan (8) } & Central & Cubeo & TOP/DISL \\
\hline & Eastern & Barasano & TOP/DISL \\
\hline & & Desano & TOP/DISL \\
\hline & & Kotiria & TOP \\
\hline & & Tucano & TOP \\
\hline & Western & Koreguaje & TOP/DISL \\
\hline & & Retuarẫ & TOP \\
\hline Tupi (1) & Tupi-Guaraní & Guaraní & TOP \\
\hline \multirow[t]{2}{*}{ Uralic (2) } & Permic & Komi & TOP \\
\hline & Ugric & Mansi (Eastern) & TOP \\
\hline Isolates (4) & & Kwaza & AN \\
\hline Cl & & Purepecha & TOP/DISL \\
\hline (5) & & Yukaghir & TOP \\
\hline (1) & & Zuni & AN \\
\hline
\end{tabular}




\section{B. Appendix: Languages in the sample with symmetric alternations $(\mathbf{N}=\mathbf{2 6})$}

\begin{tabular}{|c|c|c|c|}
\hline Family & Stock & Language & Factors \\
\hline \multirow[t]{3}{*}{ Altaic (3) } & Tungusic & Evenki & ASP/AFF/QUANT \\
\hline & & Negidal & ASP/AFF/QUANT \\
\hline & Turkic & Dolgan & ASP/AFF/QUANT \\
\hline \multirow[t]{4}{*}{ Austronesian (4) } & Oceanic & Maori & ASP/AFF/QUANT \\
\hline & & Niuean & ASP/AFF/QUANT \\
\hline & & Tongan & ASP/AFF/QUANT \\
\hline & & Tuvualuan & ASP/AFF/QUANT \\
\hline \multirow[t]{11}{*}{ Indo-European (11) } & Baltic & Lithuanian & ASP/QUANT/POL \\
\hline & Germanic & Gothic & ASP/QUANT/POL \\
\hline & & Old High German & ASP/QUANT/POL \\
\hline & & Old Saxon & ASP/QUANT/POL \\
\hline & Greek & Ancient Greek & ASP/AFF/QUANT \\
\hline & Indo-Iranian & Avestan & ASP/AFF/QUANT \\
\hline & Indo-Aryan & Vedic & ASP/AFF/QUANT \\
\hline & Slavic & Old Church Slavonic & ASP/QUANT/POL \\
\hline & & Polish & ASP/QUANT/POL \\
\hline & & Russian & ASP/QUANT/POL \\
\hline & & Slovene & ASP/QUANT/POL \\
\hline \multirow[t]{3}{*}{ Kartvelian (3) } & & Georgian & ASP \\
\hline & & Mingrelian & ASP \\
\hline & & Svan & ASP \\
\hline \multirow[t]{5}{*}{ Uralic (5) } & Finnic & Estonian & ASP/QUANT/POL \\
\hline & & Finnish & ASP/QUANT/POL \\
\hline & & Carelian & ASP/QUANT/POL \\
\hline & & Votic & ASP/QUANT/POL \\
\hline & Ugric & Hungarian & QUANT \\
\hline
\end{tabular}

Table 3: Languages showing symmetric systems with list of main parameters

\section{Abbreviations}

$\begin{array}{llll}\text { A } & & \text { HAB } & \text { habitual } \\ \text { ABL } & \text { ablative } & \text { HSY } & \text { hearsay } \\ \text { ABS } & \text { absolutive } & \text { IMP } & \text { imperative } \\ \text { ACC } & \text { accusative } & \text { INDEF } & \text { indefinite } \\ \text { ADV } & \text { adverb } & \text { IPFV } & \text { imperfective } \\ \text { AOR } & \text { aorist } & \text { M } & \text { masculine } \\ \text { ART } & \text { article } & \text { NEG } & \text { negation } \\ \text { AUX } & \text { auxiliary } & \text { NOM } & \text { nomintaive } \\ \text { CL } & \text { clitic } & \text { OBJ } & \text { object } \\ \text { CONNEG } & \text { connegative } & \text { PART } & \text { partitive } \\ \text { CONV } & \text { converb } & \text { PFV } & \text { perfective } \\ \text { DAT } & \text { dative } & \text { PL } & \text { plural } \\ \text { DEF } & \text { definite } & \text { PRS } & \text { present tense } \\ \text { DET } & \text { determiner } & \text { PST } & \text { past tense } \\ \text { DU } & \text { dual } & \text { PTCP } & \text { participle } \\ \text { ERG } & \text { ergative } & \text { RES } & \text { resultative } \\ \text { EXCL } & \text { exclamative } & \text { SG } & \text { singular } \\ \text { F } & \text { feminine } & \text { SUBJ } & \text { subject } \\ \text { GEN } & \text { genitive } & & \end{array}$




\section{References}

Abraham, Werner (1997): The interdependency of case, aspect and referentiality in the history of German: the case of the verbal genitive, in: van Kemenade, Ans \& Nigel Vincent (eds.), Parameters of morphosyntactic mhange. Cambridge: Cambridge University Press, 29-61.

Aissen, Judith (2003): Differential object marking: iconicity vs. economy, in: Natural Language and Linguistic Theory 21,435-448.

BAUER, BRIgITTE (2007): The definite article in Indo-European: emergence of a new grammatical category?, in: Stark, Elisabeth; Leiss, Elisabeth \& Abraham, Werner (eds.), Nominal determination: typology, context, constraints, and historical emergence. Amsterdam-Philadelphia: John Benjamins, 103-139.

BAUER, Winifred (1993): Maori. London: Routledge.

BEAVERs, JoHn (2010): The structure of lexical meaning: why semantics really matters, in: Language 86, $821-864$.

Beavers, John (2011): On affectedness, in: Natural Language and Linguistic Theory 29, 335-370.

Bender, Emily (2000): The syntax of mandarin bă: reconsidering the verbal analysis, in: Journal of East Asian Linguistics 9(2), 105-145.

Besnier, Niko (2000): Tuvaluan, a Polynesian language of the Central Pacific. London: Routledge.

Blake, Barry J. (1994): Case. Cambridge: Cambridge University Press.

Borg, Albert \& Mifsud, Manwel (2002): Maltese object marking in a Mediterranean context, in: Ramat, Paolo \& Stolz, Thomas (eds.), Mediterranean languages: Papers from the MEDTYP workshop. (Diversitas Linguarum 1). Bochum: N. Brockmeyer, 33-46.

Bossong, Georg (1985): Differentielle objektmarkierung in den Neuiranischen Sprachen. Tübingen: Narr.

Bossong, Georg (1998): Le marquage diffèrentiel de l'objet dans les langues d'Europe, in: Feuillet, JACK (ed.), Actance et valence dans les langues d'Europe. Berlin/New York: Mouton de Gruyter, 193-258.

Bulatova, Nadezhda \& Grenoble, Lenore (1999): Evenki. Munich: Lincom Europa.

CAughley, Ross C. (1982): The syntax and morphology of the verb in Chepang. Pacific Linguistics, Series B. Canberra: Australian National University.

Chao, Yuen-Ren (1968): A grammar of spoken Chinese. Berkeley: University of California Press.

Chung, SAndra (1978): Case marking and grammatical relations in Polynesian. Austin: University of Texas Press.

Comrie, Bernard (1989): Language typology and linguistic universals. Syntax and morphology. Oxford: Blackwell.

Croft, William (1988): Agreement vs. case marking in direct objects, in: Barlow, Michael \& Ferguson, Charles (eds.), Agreement in natural languages. Stanford: Center for the study of language and information, 159-179.

Croft, William (2001): Radical construction grammar. Oxford: Oxford University Press.

Croft, William (2003): Typology and universals. Cambridge: Cambridge University Press.

CROFT, William (2012): Verbs: aspect and argument structure. Oxford: Oxford University Press.

DAHL, EysteIN (2009): Some semantic and pragmatic aspects of object alternation in Early Vedic, in: Barmdal, Johanna \& Chelliah, Shobhana (eds.), The role of semantics and pragmatics in the development of case. Amsterdam/Philadelphia: John Benjamins, 23-55.

Dalrymple, Mary \& Nikolaeva, Irina (2011): Objects and information structure. Cambridge: Cambridge University Press.

de Hoop, Helen \& Malchukov, Andrej (2008): Case-marking strategies, in: Linguistic Inquiry 39, $565-587$.

de Swart, Peter (2006): Case markedness, in: Kulikov, Leonid; Malchukov, Andrej \& de Swart, Peter (eds.), Case, valency and transitivity. Amsterdam/Philadelphia: John Benjamins, 249-268.

De Swart, Peter (2007): Cross-linguistic variation in object marking. Utrecht: LOT Publishers.

Givón, Talmy (1976): Topic, pronoun and grammatical agreement, in: Li, Charles (ed.), Subject and topic. London-New York: Academic Press, 149-188.

GOLbBrerg, ADELE (1995): Constructions: a construction grammar approach to argument structure. Chicago: University of Chicago Press.

HArkis. Alice (1981): Georgian syntax: a study in relational grammar. Cambridge: Cambridge University Press. 
Harris, Alice (1985): Diachronic syntax: the Kartvelian case. New York: Academic Press.

Herrity, Peter (2000): Slovene: a comprehensive grammar. London: Routledge.

Holvoet, Alex (2011): The Baltic languages, in: Kortmann, Bernd \& van der Auwera, Johan (eds.), The languages and linguistics of Europe. A comprehensive guide. Berlin/New York: Mouton de Gruyter, 3-30.

Huumo, Tuomas (2003): Incremental existence: the world according to the Finnish existential sentence, in: Linguistics 41(3), 461-493.

Huumo, Tuomas (2009): Fictive dynamicity, nominal aspect, and the Finnish copulative construction, in: Cognitive Linguistics 20(1), 43-70.

Iemmolo, Giorgio (2010): Topicality and differential object marking: evidence from Romance and beyond, in: Studies in Language 34(2), 239-272.

IEмmolo, Giongio (2011): Towards a typological study of differential object marking and differential object indexation. $\mathrm{Ph} . \mathrm{D}$. thesis, University of Pavia.

Iemmolo, Giorgio \& Arcodia, Giorgio Francesco (forthcoming): Differential object marking and identifiability of the referent: a study of Mandarin Chinese, in: Linguistics 52 (2).

Jing-Schmidt, Zhuo (2005): Dramatized discourse: the Mandarin Chinese ba- construction. Amsterdam/ Philadelphia: John Benjamins.

KARLSSON, FRED (2003): Finnish: an essential grammar. London: Routledge.

Koptjevskaja-Tamm, Maria \& Wälchli, Bernhard (2001): The Circum-Baltic languages. An areal-typological approach, in: Dahl, Östen \& Koptjevskaja-Tamm, Maria (eds.), Circum-Baltic languages 2: grammar and typology. Amsterdam/Philadelphia: John Benjamins, 615-761.

Krasovitsky, Alexander; Baerman, Matthew; Brown, Dunstan \& Corbett, Greville (2011): Changing semantic factors in case selection: Russian evidence from the last two centuries, in: Morphology 21,573-592.10.1007/s11525-010-9178-x.

La Polla, Randy L. (1993): On the change to verb-medial word order in Proto- Chinese: evidence from Tibeto-Burman, in: Kitamura, H.; Nishida, T. \& Nagano, Y. (eds.), Current issues in Sino-Tibetan linguistics. Osaka: National Museum of Ethnology, 98-104.

La Polla, Randy L. (1995): Pragmatic relations and word order in Chinese, in: Downing, Pamela A. \& Noonan, Michael (eds.), Word order in discourse. Amsterdam/Philadelphia: John Benjamins, 297-329.

Laca, Brenda (1995): Sobre el uso del acusativo preposicional en español, in: Pensado, Carmen (ed.), El complemento directo preposicional. Madrid: Visor Libros, 61-91.

Leonetti, Manuel (2004): Specificity and differential object marking in Spanish, in: Catalan Journal of Linguistics 3(1), 75-114.

LEVIN, BETH (1993): English verb classes and alternations: a preliminary investigation. Chicago: University of Chicago Press.

Levin, Beth \& Rappaport Hovav, Malka (2005): Argument realization. Oxford: Oxford University Press.

Li, Charles N. \& Thompson, Sandra (1981): Mandarin Chinese: a functional reference grammar. Berkeley: University of California Press.

Li, Yen-Hui Audrey (1990): Order and constituency in Mandarin Chinese. Dordrecht: Kluwer.

Li, Yen-Hui Audrey (2006): Chinese $b a$, in: Martin, Everaert \& van Riemsdijk, Henk (eds.), The Blackwell companion to syntax, volume 1. Oxford: Blackwell, 374-468.

LiU, FeNG-Hsi (1997): An aspectual analysis of ba, in: Journal of East Asian Linguistics 6(1), 51-99.

Liu, Feng-Hsi (2007): Word order variation and ba sentences in Chinese, in: Studies in Language 31(3), 649-682.

Lunt, Horace (2001): Old Church Slavonic grammar. Berlin/New York: Mouton de Gruyter.

LURAGHI, SiLVIA ms: Partitives and differential marking of core arguments: a cross-linguistic survey.

Luraghi, Silvia \& Kittilä, Seppo (in press): Typology and diachrony of partitive case markers, in: Luraghi, Silvia \& Huumo, Tuomas (eds.), Partitive cases and related categories. Berlin: Mouton de Gruyter.

Malchukov, Andrej (2005): Case pattern splits, verb types and construction competition, in: Amberber, Mengistu \& DE Hoop, Helen (eds.), Competition and variation in natural languages: the case for case. Amsterdam: Elsevier, 73-118.

Marcantonio, Angela (1985): On the definite vs. indefinite conjugation in Hungarian: a typological and diachronic analysis, in: Acta Linguistica Scientiarum Hungaricae 35, 267-298.

McCloskey, James \& Hale, Kenneth (1983): On the syntax of person-number inflection in Modern Irish, in: Natural Language and Linguistic Theory 1(4): 487-533. 
Moravcsik, Edith (1978): On the case marking of objects, in: Greenberg, Joseph; Ferguson, Charles \& MoravcsiK, EdiTH (eds.), Universals of human language. Syntax, vol. 4. Stanford: Stanford University Press, 249-290.

NÆSS, ÅsHILD (2004): What markedness marks: the markedness problem with direct objects, in: Lingua $114,1186-1212$.

NÆSS, ÅSHILD (2007): Prototypical transitivity. Amsterdam/Philadelphia: John Benjamins.

NAPOLI, MARIA (2010): The case for the partitive case: the contribution of ancient greek, in: Transactions of the Philological Society 108(1), 15-40.

Nedjalkov, IgOR (1997): Evenki. London: Routledge.

PAKendorf, BrigitTe (2007): Contact in the prehistory of the Sakha (Yakuts): linguistic and genetic perspectives. Utrecht: LOT Publishers.

Pensado, Carmen (1995): La creación del objeto directo preposicional y la flexión de los pronombres personales en las lenguas románicas, in: Pensado, CARMEN (ed.), El complemento directo preposicional. Madrid: Visor Libros, 179-233.

Peyraube, Alain (1985): Les structures en ba en chinois medieval et moderne, in: Cahiers de Linguistique Asie-Orientale 14(1),193-213.

PhilipPi, Julia (1997): The rise of the article in the Germanic languages, in: van Kemenade, Ans \& ViNCENT, Nigel (eds.), Parameters of morphosyntactic change. Cambridge: Cambridge University Press, 62-93.

Przepiórkowski, AdAm (2000): Long distance genitive of negation in Polish, in: Journal of Slavic Linguistics 8,151-189.

Sands, Kristina \& Campbell, Lyle (2001): Non-canonical subjects and objects in Finnish, in: Aikhenvald, Aleksandra Y.; Dixon, Robert M. W. \& Onishi, Masayuki (eds.), Non-canonical marking of subjects and objects. Amsterdam: John Benjamins, 251-306.

Seiter, William (1980): Studies in Niuean syntax. New York: Garland.

SKRIBNIK, Elena (2001): Variation of noun phrase markers in Siberian languages, in: Boeder, WiNFrIED \& Hentschel, Gerd (eds.), Variierende Markierung von Nominalgruppe in Sprachen unterschiedlichen Typs. Oldenburg: Oldenburg, Bibliotheks- und Informationssystem der Universität Oldenburg, 345-364.

Sun, CHAO-Fen (1996): Word order change and grammaticalization in the history of Chinese. Stanford: Stanford University Press.

Sybesma, Rint (1992): Causatives and accomplishments: the case of Chinese $b a$. Ph. D. thesis, Leiden University.

TSUNODA, TASAKU (1985): Remarks on transitivity, in: Journal of Linguistics 21,385-396.

von Heusinger, Klaus (to appear): Specificity, in: von Heusinger, Klaus; Maienborg, Claudia \& PortNER, PAUL (eds.), Semantics: an international handbook of natural language meaning, vol. 2: Berlin/ New York: Mouton de Gruyter.

von Heusinger, Klaus \& Kaiser, Georg (2011): Affectedness and differential object marking in Spanish, in: Morphology 21,593-617.

WADE, TeRENCE (2011): A comprehensive Russian grammar. Oxford: Blackwell.

Wright, Joseph (1910): Grammar of the Gothic language, and the Gospel of St. Mark: selections from the other Gospels, and the Second Epistle to Timothy, with notes and glossary. Oxford: Clarendon Press.

YANG, NING (2008): The indefinite object in Mandarin Chinese: its marking, interpretation and acquisition. Utrecht: LOT Publishers.

YANG, Ning \& van Bergen, Geertie (2007): Scrambled objects and case marking in Mandarin Chinese, in: Lingua 9, 1617-1635.

Yip, Po-Ching \& Rimmington, Don (2004): Chinese: a comprehensive grammar. London: Routledge.

\section{Giorgio Iemmolo}

Department of General Linguistics

University of Zurich

Plattenstr. 54

CH- 8032 Zurich

SWITZERLAND

jorg10.1emmolo@uzh.ch 